\title{
Structure and dynamics of surface uplift induced by incremental sill
}

\section{emplacement}

\author{
Craig Magee ${ }^{1}$, Ian D. Bastow ${ }^{1}$, Benjamin van Wyk de Vries², Christopher A.-L. Jackson ${ }^{1}$, Rachel Hetherington ${ }^{3}$, \\ Miruts Hagos ${ }^{4}$, and Murray Hoggett ${ }^{5}$ \\ 1Department of Earth Science and Engineering, Imperial College, London SW7 2BP, UK \\ 2Université Clermont Auvergne, CNRS, IRD, OPGC, Laboratoire Magmas et Volcans, F-63000 Clermont-Ferrand, France \\ ${ }^{3}$ Department of Geological and Mining Engineering and Sciences, Michigan Technological University, Houghton, Michigan 49931, USA \\ ${ }^{4}$ Department of Earth Sciences, Mekelle University, P.O. Box 231, Mekelle, Tigray, Ethiopia \\ ${ }^{5}$ School of Geography, Earth and Environmental Science, University of Birmingham, Birmingham B15 2TT, UK
}

\begin{abstract}
Shallow-level sill emplacement can uplift Earth's surface via forced folding, providing insight into the location and size of potential volcanic eruptions. Linking the structure and dynamics of ground deformation to sill intrusion is thus critical in volcanic hazard assessment. This is challenging, however, because (1) active intrusions cannot be directly observed, meaning that we rely on transient host-rock deformation patterns to model their structure; and (2) where ancient sill-fold structure can be observed, magmatism and deformation has long since ceased. To address this problem, we combine structural and dynamic analyses of the Alu dome, Ethiopia, a 3.5-km-long, 346-m-high, elliptical dome of outward-dipping, tilted lava flows cross-cut by a series of normal faults. Vents distributed around Alu feed lava flows of different ages that radiate out from or deflect around its periphery. These observations, coupled with the absence of bounding faults or a central vent, imply that Alu is not a horst or a volcano, as previously thought, but is instead a forced fold. Interferometric synthetic aperture radar data captured a dynamic growth phase of Alu during a nearby eruption in A.D. 2008, with periods of uplift and subsidence previously attributed to intrusion of a tabular sill at $1 \mathrm{~km}$ depth. To localize volcanism beyond its periphery, we contend that Alu is the first forced fold to be recognized to be developing above an incrementally emplaced saucershaped sill, as opposed to a tabular sill or laccolith.
\end{abstract}

\section{INTRODUCTION}

Emplacement of shallow-level magma reservoirs is commonly accommodated by uplift of the overlying rock and free surface. Ground deformation monitoring, such as by interferometric synthetic aperture radar (InSAR), can thus be used to track magma movement and accumulation (e.g., Pagli et al., 2012). A salient assumption when inverting geodetic data for intrusion shape is that the location, geometry, and volume of surface uplift and/or subsidence equal those of the magma body (Galland, 2012). This assumption is partly based on field analyses of sills and laccoliths, which show that space can be generated by folding of overlying rock (e.g., Pollard and Johnson, 1973; van Wyk de Vries et al., 2014). These folds are termed forced folds, because their overall geometry mimics and is controlled by the shape of an underlying sill or laccolith (Stearns, 1978; van Wyk de Vries et al., 2014). Forced fold growth can influence the distribution, structure, and stability of volcanoes (e.g., Magee et al., 2013a; van Wyk de Vries et al., 2014). Understanding structural and dynamic interactions between intrusions, forced folding, and volcanism thus underpins the application of geodetic data to volcanology.

Recent field-, modeling-, and seismic reflection-based studies have questioned the accuracy of intrusion geometries inverted from ground deformation. For example, geodetically derived intrusion shapes are too simple compared to the complex geometries seen in natural examples (e.g., Galland, 2012). In addition to elastic bending, inelastic space-making mechanisms can also accommodate magma, meaning that the volume of surface uplift may differ from that of the underlying intrusion (e.g., Galland and Scheibert, 2013; Wilson et al., 2016). To fully utilize geodetic data when tracking magma within and characterizing the plumbing system of active volcanoes, it is critical to discern how intrusions are expressed at the Earth's surface.

Constraining geometric and temporal relationships between intrusion and forced folding is, however, challenging because (1) the dynamic, short-time-scale ( $<1$ m.y.) evolution of ancient forced folds, where magmatism has long since ceased, is difficult to elucidate (e.g., Magee et al., 2014); and (2) geodetically derived modeling solutions for transient intrusion events are simple and, critically, non-unique (Galland, 2012). To address these problems, analyses of actively deforming forced folds for which the geological history can be reconstructed are required. The Erta'Ale volcanic segment in the Danakil depression, a rift basin in northern Ethiopia (Fig. 1A), is a superb natural laboratory for studying the surface expression of active magmatism. Geodetic data from several volcanoes within the Erta'Ale volcanic segment have linked ground deformation to the growth of silllike reservoirs (Amelung et al., 2000; Nobile et al., 2012; Pagli et al., 2012). In particular, Pagli et al. (2012) suggested that uplift and subsidence (of up to $1.9 \mathrm{~m}$ ) during the A.D. 2008 eruption at the Alu-Dalafilla volcanic center (Fig. 1B) occurred in response to inflation and deflation of a tabular sill, which correlates spatially with the Alu and Alu South domes. Here, we combine structural mapping and dynamic analyses of ground deformation and extrusions at Alu to constrain how magmatism has been expressed at the surface through time.

\section{STRUCTURE OF THE ALU DOME AND SURROUNDING LAVA FIELD}

The actively extending Danakil depression is a NNW-trending, 120-km-long, 50-kmwide half-graben that contains a thick $(>1 \mathrm{~km})$ sequence of siliciclastics, carbonates, and evaporites (Hutchinson and Engels, 1970). The Alu dome, located $\sim 30 \mathrm{~km}$ north of Erta'Ale and covered by basaltic lavas (Figs. 1 and 2A), has previously been interpreted as either a horst (Barberi and Varet, 1970) or a volcano (Pagli et al., 2012; Hagos et al., 2016). In addition to Alu, the Alu-Dalafilla volcanic center includes a 3-kmlong basaltic ridge (i.e., the Alu South dome; Pagli et al., 2012) and the Dalafilla stratovolcano (Fig. 1B) (Barberi and Varet, 1970).

Satellite images reveal that Alu is elliptical $(3.5 \times 2 \mathrm{~km})$, with a NNW-trending long axis subparallel to the local rift axis (Figs. 1 and 2A). Alu has a peak elevation of $397 \mathrm{~m}$ above sea level and an amplitude of $\sim 346 \mathrm{~m}$, assuming a 

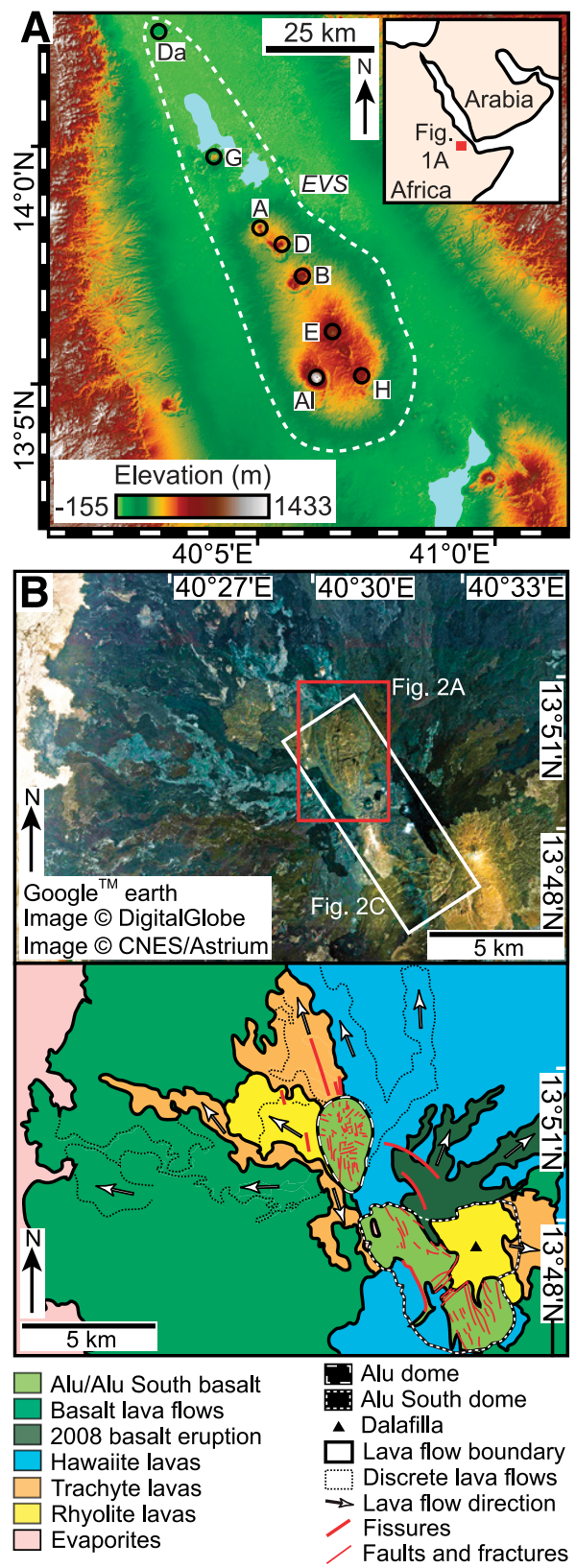

Figure 1. A: Topography of Erta'Ale volcanic segment (EVS), Danakil depression, Ethiopia. Ale Bagu (AI), Hayli Gabbi (H), Erta'Ale (E), Borale'Ale (B), Alu (A), Dalafilla (D), Gada'Ale $(G)$, and Dallol (Da) volcanic centers are highlighted. B: Uninterpreted and interpreted Google Earth ${ }^{\mathrm{TM}}$ satellite image of Alu-Dalafilla volcanic center and surrounding lavas (based on Barberi and Varet, 1970; Pagli et al., 2012).

horizontal pre-dome datum (Fig. 2B); the aspect ratio $(L / A)$ of its length $(L)$ to its amplitude $(A)$ is 10.1. The lateral limits of Alu, Alu South, and an underlying sill modeled using InSAR data are co-located (Fig. 2C); the inferred tabular sill is $10 \mathrm{~km}$ long and located at a depth of $1 \mathrm{~km}$ (e.g., Fig. 2B) (Pagli et al., 2012). An array of NNWand ENE-striking normal faults and tensional fractures cross-cut Alu but do not encircle or extend beyond its mapped limit (Fig. 2A). Five
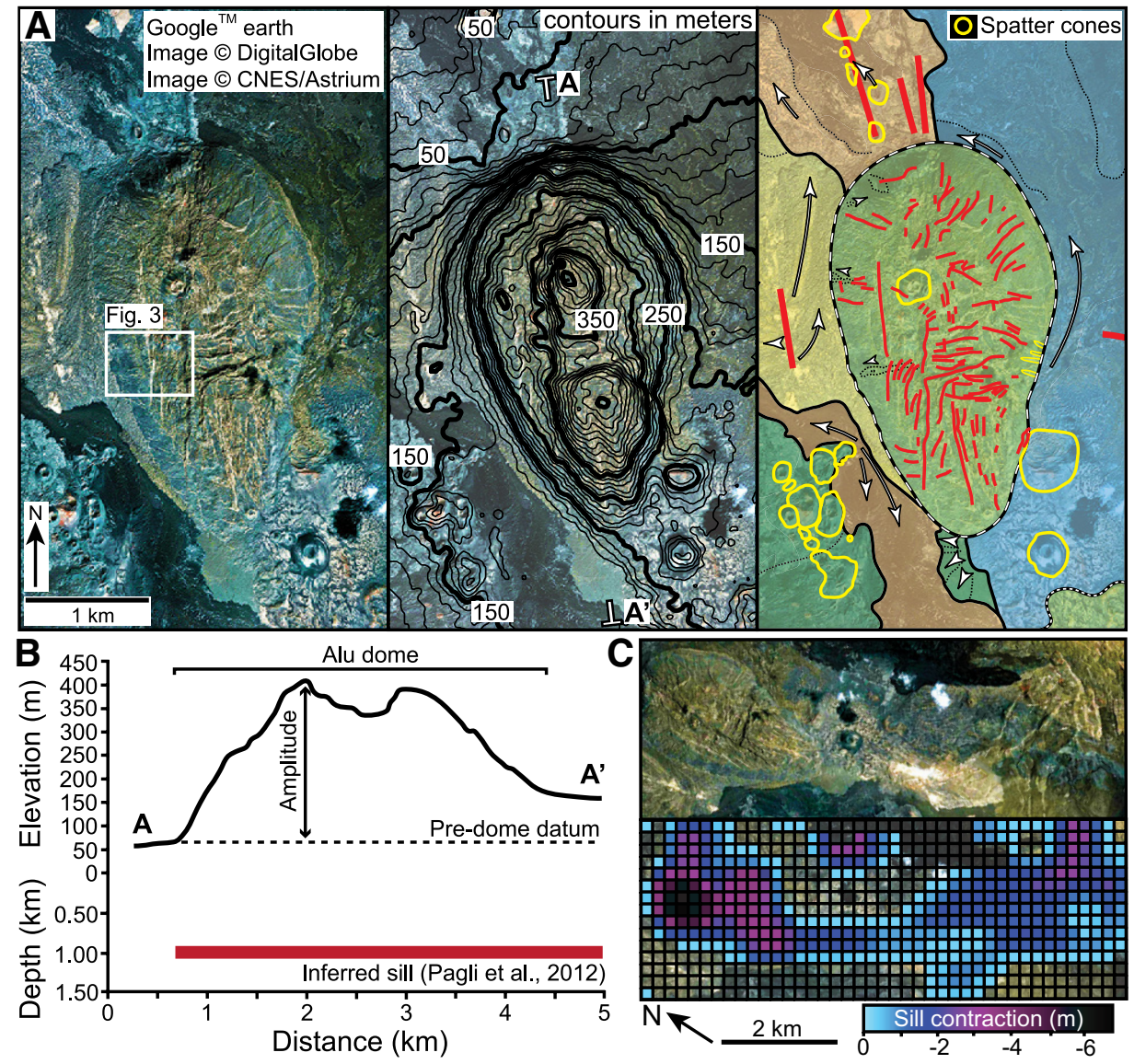

Figure 2. A: Uninterpreted and interpreted Google Earth ${ }^{\mathrm{TM}}$ satellite images of Alu dome (Ethiopia; see Fig. 1B for key and location). Only major fractures and faults are interpreted. B: Topographic profile across Alu (see A for location) and position of sill modeled from InSAR data (Pagli et al., 2012). C: Uninterpreted Google Earth ${ }^{\mathrm{TM}}$ satellite image of Alu and Alu South and the same image overlain by a map of sill contraction facilitating subsidence recorded by InSAR data in 2008 (see Fig. 1B for location) (redrawn from Pagli et al., 2012).

discrete lava flow channels, cross-cut by the array of fractures/faults, are observed on the slopes and summit of Alu; pressure ridges, pahoehoe lobes, channel levees, and intra-flow islands suggest that most lava flow directions are oriented downslope with one oriented obliquely upslope (Figs. 2A and 3). The only major vent is a spatter cone, offset from the summit, which does not appear to feed dome lavas and is faulted (Fig. 2A)

Cross-cutting relationships between lava flows surrounding Alu reveal a broadly basaltic to rhyolitic evolutionary sequence, with the exception of a basalt eruption in 2008 (Fig. 1B) (Barberi and Varet, 1970; Pagli et al., 2012). Ropey flow textures and lobe terminations within the lavas indicate that extrusion sites are typically situated $<2 \mathrm{~km}$ from Alu; most lavas appear to emanate from point sources (e.g., the trachyte lava to the southwest of Alu) but others can be traced back to fissures that are either radial to Alu (e.g., along its eastern base) or northwest trending (e.g., to the west of Alu) (Figs. 1B and 2A). Five spatter cones north of Alu are aligned along and may genetically relate to a northwest-trending fissure, but spatter cones to the southwest and southeast of Alu are not associated with clear fissures (Fig. 2A). Some of the spatter cones to the southwest of Alu are aligned approximately northwest-southeast (Fig. 2A).

\section{ORIGIN AND GROWTH OF THE ALU \\ DOME AND SURROUNDING LAVA FIELD}

Previous interpretations that the Alu dome is a horst (Barberi and Varet, 1970) or a volcano

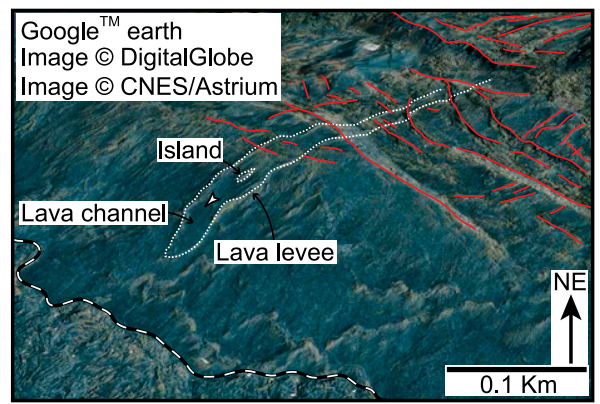

Figure 3. Levee-bound lava channel that flowed around island of older basalt, Alu dome (Ethiopia; see Fig. 2A for location). Vertical exaggeration $=1.5 \times$ 
(Pagli et al., 2012; Hagos et al., 2016) are largely incompatible with our observations: Alu is not bound by faults, and, while it is similar in size to small, subaerial volcanoes (Fig. 4), there is no central vent (Fig. 2A). Furthermore, lavas on Alu display evidence of tilting: the upslope-oriented flow direction, lava levees, and intra-flow islands are consistent with extrusion onto a subhorizontal surface and are cross-cut by fractures/faults (Figs. 2A and 3). Alu was therefore not wholly constructed by the buildup of lava flows but rather grew after extrusion by flexure and faulting. We suggest that the Alu dome is a forced fold because (1) its boundary coincides with the lateral limit of an underlying sill inferred from geodetic data (Figs. 2B and 2C) (cf. Pagli et al., 2012; Magee et al., 2013b); (2) forced folds have dome-like geometries comparable in size to Alu (Fig. 4); (3) normal faults and tensional fractures, similar to those that cross-cut Alu (e.g., Fig. 2A), commonly occur during forced folding due to outer-arc extension (e.g., Pollard and Johnson, 1973; Magee et al., 2013b); and (4) forced folds are onlapped by and can influence routing of syn-growth and younger sediment or lava, like at Alu (e.g., Figs. 1B and 2A) (Magee et al., 2014). Similarities in size and shape between forced folds, including Alu, and volcanoes suggest that intrusion-induced uplift may influence final volcano morphology (Fig. 4) (van Wyk de Vries et al., 2014). Henceforth, we refer to the Alu dome as a forced fold, formed in response to emplacement of an underlying magma body.
Formation of Alu began prior to the extrusion of the surrounding lavas, which deflect around the forced fold (Figs. 1B and 2A). Without radiometric dates for the surrounding lavas, it is impossible to constrain the onset of intrusion and doming. The volume and variety of lavas imply that intrusion and folding began centuries ago, but historical records do not predate Alu's existence. Intrusion prior to the 2008 Alu-Dalafilla eruption cycle is compatible with InSAR measurements, which suggests a discrepancy between the volume of injected $\left(\sim 0.4 \times 10^{6} \mathrm{~m}^{3}\right)$ and erupted magma $\left(\sim 25.4 \times 10^{6} \mathrm{~m}^{3}\right)$; i.e., the extra $23.2 \times 10^{6} \mathrm{~m}^{3}$ of lava erupted was already present as melt beneath Alu (Pagli et al., 2012). This discrepancy in injected and erupted volumes provides evidence for incremental emplacement of distinct magma pulses at Alu, consistent with the current paradigm for sill and laccolith construction (e.g., Cruden and McCaffrey, 2001; Magee et al., 2014). Forced folds, like Alu, may thus reflect a complex growth history involving multiple uplift and subsidence events.

Given that InSAR data collected during the 2008 eruption only captured the latest injection of magma, the tabular sill modeled by Pagli et al. (2012) likely does not represent the true geometry of the Alu intrusion. Because the shape of a forced fold is typically controlled by that of the underlying forcing member (Stearns, 1978), the topographic expression of Alu may suggest that it formed above a laccolith because (1) the morphology of Alu is reminiscent of flat-topped

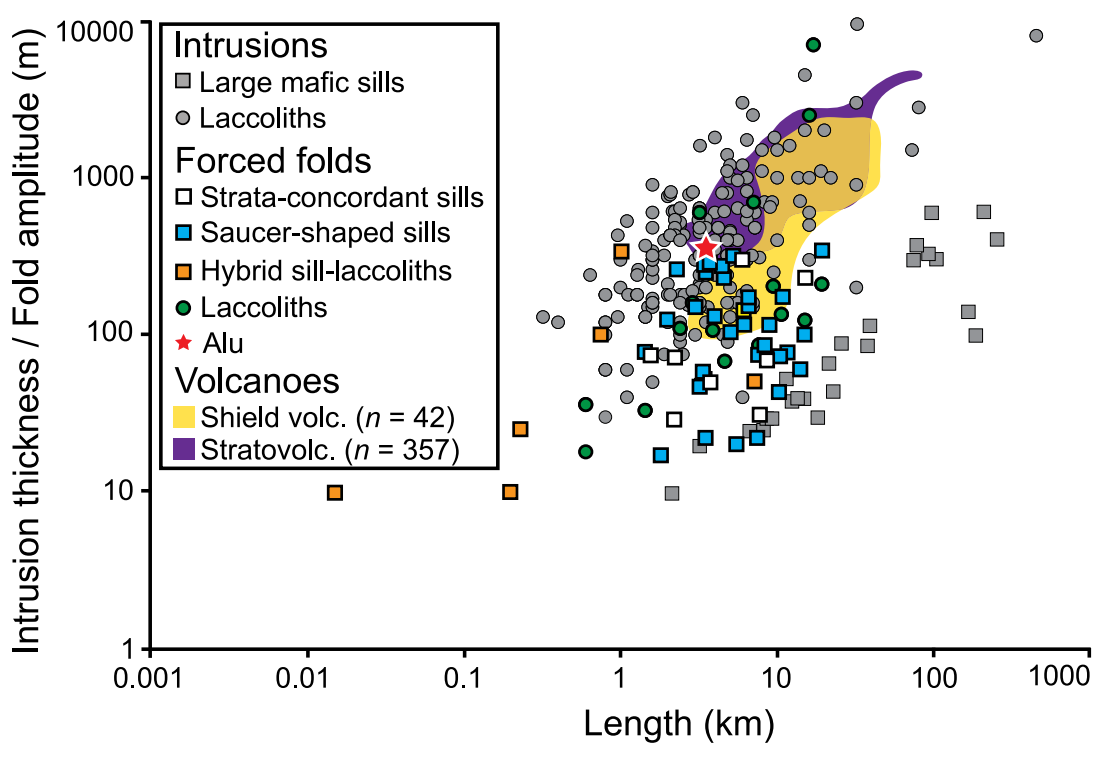

Figure 4. Length plotted against forced fold amplitude, for folds above differently shaped intrusions, and thickness of laccoliths and large mafic sills (Tables DR1 and DR2 in the GSA Data Repository ${ }^{1}$ ). Alu dome (Ethiopia) is shown with red star. Fields for individual, subaerial shield volcano and stratovolcano lengths and heights are also shown (Grosse et al., 2014).

${ }^{1}$ GSA Data Repository item 2017129, Table DR1 (sill and laccolith measurements) and Table DR2 (forced fold measurements) with the intrusion and forced fold lengths and thicknesses/amplitudes obtained from the literature and used in Figure 4, is available online at http://www.geosociety.org/datarepository/2017/ or on request from editing@geosociety.org. laccoliths with steep sides (e.g., Fig. 2B) (Cruden et al., 2017); and (2) the aspect ratio of Alu $(L / A=10.1)$ equals the mean aspect ratio of laccoliths $(L / T=10)$ (Corry, 1988; McCaffrey and Petford, 1997; Bunger and Cruden, 2011). However, where underlying intrusions can be assessed, e.g., in seismic reflection data (e.g., Jackson et al., 2013), forced folds that developed above laccoliths and sills can have similar geometries (Fig. 4). The size and shape of Alu, which is similar to those of both laccolith- and sill-induced forced folds (Fig. 4), therefore cannot be used to conclusively define the underlying intrusion geometry (cf. Castro et al., 2016).

Deflection of lava flows around Alu and the radial disposition of flow trajectories suggest that the surrounding lavas post-date initial dome growth (Figs. 1B and 2A). Although most lavas in volcanic segments in Danakil are considered to be fed by NNW-trending fissures delineating rift-parallel dikes (Barberi and Varet, 1970), several extrusion sites in the vicinity of Alu have point-like geometries (Fig. 2A). Lavas and spatter cones, which are not aligned along northwest-trending fissures and dikes, may instead have been sourced from beneath Alu, not from rift-parallel dikes. Sill-fed vents and lavas commonly overlie lateral intrusion tips, particularly of saucer-shaped sills, and thus occur along or beyond the periphery of forced folds (e.g., Galland, 2012; Magee et al., 2013a). In contrast, laccolith-fed extrusions typically emanate from vents located on the forced fold (e.g., Henry et al., 1997; Acocella et al., 2001). Given the disposition of the mapped spatter cones and extrusion sites beyond Alu, coupled with the inferred location and depth of intrusion (i.e., $1 \mathrm{~km}$ ), we suggest that Alu is underlain by a saucer-shaped sill and not a tabular sill or a laccolith (Fig. 5). The origin of the lava-feeding fissure and the northwest-trending spatter cones immediately to the west and southwest of Alu, respectively, is difficult to determine; these extrusions could be fed from either rift-parallel dikes or the inclined limb of a saucer-shaped sill, which is expected to parallel the local approximately northwest-southeast trend of the Alu outline (Fig. 2A). Elongation of Alu parallel to the rift

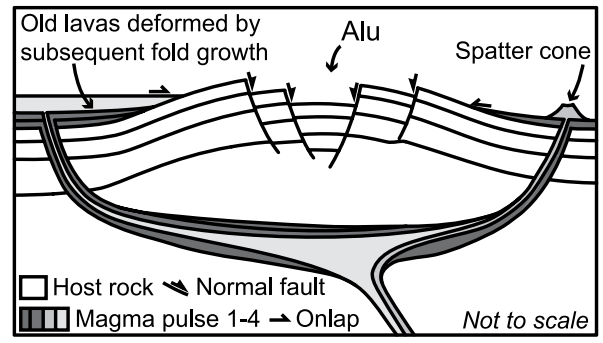

Figure 5. Schematic cross-section of saucershaped sill, constructed by injection of distinct magma pulses, inferred to have formed Alu dome (Ethiopia) forced fold and to have fed surrounding lavas. 
axis implies that the saucer-shaped sill could be dike fed (Galerne et al., 2011).

Like Alu, the Alu South dome and Dalafilla stratovolcano are uplifted relative to the surrounding lava-field and were deformed during the 2008 eruption (Fig. 2C) (Pagli et al., 2012). Alu South is also cross-cut by normal faults and tensional fractures (Fig. 1B). We suggest that Alu South and some component of the growth history of Dalafilla can be attributed to intrusion-induced uplift (e.g., van Wyk de Vries et al., 2014).

\section{CONCLUSIONS}

Ground deformation commonly heralds eruptions at active volcanoes, providing real-time insights into the location and geometry of subsurface intrusions. To constrain the evolution of ground deformation beyond transient events captured by geodetic data, we examined the structural and extrusive history of the Alu dome, Ethiopia. Surface uplift and subsidence in 2008, recorded by InSAR during a nearby eruption, reveals that Alu is actively deforming; these ground deformation patterns were attributed to deformation of a volcano above a tabular sill. Because the lateral terminations of this inferred sill directly underlie the boundary of Alu, we suggest that Alu is a forced fold. Alu also lacks a central vent and evidence for construction by lava flow accumulation; lavas on the dome have been tilted post-emplacement, while surrounding flows deflect around Alu, implying pre-eruption topography. Normal faults cross-cut Alu, consistent with syn-doming outer arc extension. Alu resembles a laccolith in shape and size, but we show that forced folds above sills and laccoliths are commonly indistinguishable from their geometry alone. Our observations, coupled with evidence for lava flows emanating and radiating from vents/spatter cones around its periphery, demonstrate that Alu is a forced fold developing above an incrementally emplaced saucer-shaped sill. Intrusion geometries inferred from the topographic expression of long-lived magma bodies, like those modeled from geodetic data, are thus non-unique. By integrating geodetic data and structural mapping, we show that ground deformation at Alu-Dalafilla in 2008 captured the first, real-time evidence for dynamic forced folding above a saucer-shaped sill.

\section{ACKNOWLEDGMENTS}

Magee is funded by an Imperial College Junior Research Fellowship. A. Cruden, S. Planke, O. Galland, and P. Wilson provided insightful reviews. B. Holdsworth is thanked for editorial handling. Université Clermont Auvergne undergraduates J. Carlier, G. Agrain, and R. Buso aided mapping.

\section{REFERENCES CITED}

Acocella, V., Cifelli, F., and Funiciello, R., 2001, The control of overburden thickness on resurgent domes: Insights from analogue models: Journal of Volcanology and Geothermal Research, v. 111, p. 137-153, doi:10.1016/S0377-0273(01)00224-4.

Amelung, F., Oppenheimer, C., Segall, P., and Zebker, H., 2000, Ground deformation near Gada 'Ale Volcano, Afar, observed by radar interferometry: Geophysical Research Letters, v. 27, p. 30933096, doi:10.1029/2000GL008497.

Barberi, F., and Varet, J., 1970, The Erta Ale volcanic range (Danakil depression, northern Afar, Ethiopia): Bulletin Volcanologique, v. 34, p. 848-917, doi:10.1007/BF02596805.

Bunger, A.P., and Cruden, A.R., 2011, Modeling the growth of laccoliths and large mafic sills: Role of magma body forces: Journal of Geophysical Research, v. 116, B02203, doi:10.1029/2010JB007648.

Castro, J.M., Cordonnier, B., Schipper, C.I., Tuffen, H., Baumann, T.S., and Feisel, Y., 2016, Rapid laccolith intrusion driven by explosive volcanic eruption: Nature Communications, v. 7, 13585, doi:10.1038/ncomms 13585 .

Corry, C.E., 1988, Laccoliths: Mechanics of Emplacement and Growth: Geological Society of America Special Paper 220, 114 p. doi:10.1130 /SPE220-p1.

Cruden, A.R., and McCaffrey, K.J.W., 2001, Growth of plutons by floor subsidence: Implications for rates of emplacement, intrusion spacing and meltextraction mechanisms: Physics and Chemistry of the Earth, Part A: Solid Earth and Geodesy, v. 26, p. 303-315, doi:10.1016/S1464-1895(01) 00060-6.

Cruden, A.R., McCaffrey, K.J.W., and Bunger, A.P., 2017, Geometric scaling of tabular igneous intrusions: Implications for emplacement and growth, in Breitkreuz, C., and Rocchi, S., eds., Physical Geology of Shallow Magmatic Systems: Springer, Advances in Volcanology (in press).

Galerne, C.Y., Galland, O., Neumann, E.-R., and Planke, S., 2011, 3D relationships between sills and their feeders: Evidence from the Golden Valley Sill Complex (Karoo Basin) and experimental modelling: Journal of Volcanology and Geothermal Research, v. 202, p. 189-199, doi:10.1016/j .jvolgeores.2011.02.006.

Galland, O., 2012, Experimental modelling of ground deformation associated with shallow magma intrusions: Earth and Planetary Science Letters, v. 317, p. 145-156, doi:10.1016/j.epsl.2011.10 017 .

Galland, O., and Scheibert, J., 2013, Analytical model of surface uplift above axisymmetric flat-lying magma intrusions: Implications for sill emplacement and geodesy: Journal of Volcanology and Geothermal Research, v. 253, p. 114-130, doi: 10.1016/j.jvolgeores.2012.12.006.

Grosse, P., Euillades, P.A., Euillades, L.D., and van Wyk de Vries, B., 2014, A global database of composite volcano morphometry: Bulletin of Volcanology, v. 76, 784, doi:10.1007/s00445-013-0784-4.

Hagos, M., Koeberl, C., and van Wyk de Vries, B., 2016, The Quaternary volcanic rocks of the northern Afar Depression (northern Ethiopia): Perspectives on petrology, geochemistry, and tectonics: Journal of African Earth Sciences, v. 117, p. 29-47, doi:10.1016/j.jafrearsci.2015.11.022.

Henry, C.D., Kunk, M.J., Muehlberger, W.R., and McIntosh, W., 1997, Igneous evolution of a complex laccolith-caldera, the Solitario, Trans-Pecos Texas: Implications for calderas and subjacent plutons: Geological Society of America Bulletin, v. 109 , p. 1036-1054, doi:10.1130/0016-7606 (1997) $109<1036$ :IEOACL $>2.3 . C O ; 2$.
Hutchinson, R., and Engels, G., 1970, Tectonic significance of regional geology and evaporite lithofacies in northeastern Ethiopia: Philosophical Transactions of the Royal Society of London, Series A: Mathematical and Physical Sciences, v. 267, p. 313-329, doi:10.1098/rsta.1970.0038.

Jackson, C.A.-L., Schofield, N., and Golenkov, B., 2013, Geometry and controls on the development of igneous sill-related forced folds: A 2-D seismic reflection case study from offshore southern Australia: Geological Society of America Bulletin, v. 125, p. 1874-1890, doi:10.1130/B30833.1.

Magee, C., Hunt-Stewart, E., and Jackson, C.A.-L., 2013a, Volcano growth mechanisms and the role of sub-volcanic intrusions: Insights from 2D seismic reflection data: Earth and Planetary Science Letters, v. 373, p. 41-53, doi:10.1016/j.epsl.2013 .04.041.

Magee, C., Briggs, F., and Jackson, C.A.-L., 2013b, Lithological controls on igneous intrusion-induced ground deformation: Journal of the Geological Society, v. 170, p. 853-856, doi:10.1144 /jgs2013-029.

Magee, C., Jackson, C.A.-L., and Schofield, N., 2014, Diachronous sub-volcanic intrusion along deepwater margins: Insights from the Irish Rockall Basin: Basin Research, v. 26, p. 85-105, doi: 10.1111/bre.12044.

McCaffrey, K., and Petford, N., 1997, Are granitic intrusions scale invariant?: Journal of the Geological Society, v. 154, p. 1-4, doi:10.1144/gsigs 154.1.0001.

Nobile, A., Pagli, C., Keir, D., Wright, T.J., Ayele, A., Ruch, J., and Acocella, V., 2012, Dike-fault interaction during the 2004 Dallol intrusion at the northern edge of the Erta Ale Ridge (Afar, Ethiopia): Geophysical Research Letters, v. 39, L19305, doi:10.1029/2012GL053152.

Pagli, C., Wright, T.J., Ebinger, C.J., Yun, S.-H., Cann, J.R., Barnie, T., and Ayele, A., 2012, Shallow axial magma chamber at the slow-spreading Erta Ale Ridge: Nature Geoscience, v. 5, p. 284-288, doi:10.1038/ngeo1414.

Pollard, D.D., and Johnson, A.M., 1973, Mechanics of growth of some laccolithic intrusions in the Henry Mountains, Utah, II: Bending and failure of overburden layers and sill formation: Tectonophysics, v. 18, p. 311-354, doi:10.1016/0040 1951(73)90051-6.

Stearns, D.W., 1978, Faulting and forced folding in the Rocky Mountains foreland, in Matthew, V., III, ed., Laramide Folding Associated with Basement Block Faulting in the Western United States: Geological Society of America Memoir 151, p. 1-38, doi:10.1130/MEM151-p1.

van Wyk de Vries, B., Márquez, A., Herrera, R., Bruña, J.G., Llanes, P., and Delcamp, A., 2014, Craters of elevation revisited: Forced-folds, bulging and uplift of volcanoes: Bulletin of Volcanology, v. 76, p. 1-20, doi:10.1007/s00445-014-0875-x.

Wilson, P.I., McCaffrey, K.J., Wilson, R.W., Jarvis, I., and Holdsworth, R.E., 2016, Deformation structures associated with the Trachyte Mesa intrusion, Henry Mountains, Utah: Implications for sill and laccolith emplacement mechanisms: Journal of Structural Geology, v. 87, p. 30-46, doi:10.1016 /j.jsg.2016.04.001.

Manuscript received 28 November 2016

Revised manuscript received 19 January 2017

Manuscript accepted 20 January 2017

Printed in USA 